\title{
頭頸部悪性腫瘍患者の免疫学的パラメーターの検討
}

\author{
與田 順一・斉藤 匡人・川口 隆明 \\ 新井 宏紀・田端 敏秀
}

\section{Clinical Evaluation of Immunological Parameters in Patients with Malignant Tumors of Head and Neck}

\author{
Junichi Yoda, Tadahito Saito, Takaaki Kawaguchi, \\ Hiroki Arai and Toshihide Tabata
}

(Wakayama Medical College)

\begin{abstract}
Since 1980, a new approach of adoptive immunotherapy has developed. It has become more necessary to evaluate the immunological conditions in tumor-bearing hosts for treatment. Recent studies of cytokines and effector cells have clarified the tumor-host immune reaction.

The present paper reviews the immunological parameters to understand the immunological conditions and prognosis of the patients with malignant tumors of head and neck.
\end{abstract}

Key words: immunological parameter, malignant tumor, head and neck

はじめに

免疫学の進歩にともない, 種々の疾患の解明, 治療に免疫学が取り入れられている.とくに， 1980年代になって, 癌治療においては養子免疫 療法 (adoptive immunotherapy) の開発, 導入 がなされつつある。異物から生体を守るといら ことが正常個体ではごく自然に行なわれている わけであるが, 癌細胞は, この免疫学的監視機 構 (immunological surveillance) をすり拔けて 発育する。そこには, 癌細胞を非自己と認識す るか否かといら問題と宿主の免疫能が正常に作 動しているかといら問題がある. 宿主の免疫能 を知ることは, 癌の治療に拈いてのみならず, 予防, 早期発見, 再発について多くの情報を提 供してくれる。ここでは, 頭頸部悪性腫瘍患者
の免疫学的パラメーターについて, 当教室の成 績をもとに in vivo, in vitroにわけて検討を加 光る。

\section{I . in vivo}

遅延型皮膚反応が広く利用されている. PPD, candida 抗原皮内反応, DNCB (2, 4dinitrochlorobenzen) 貼布試験などがある. 遠 隔転移群で PPD 皮内反応の陰性化が多く認め られ（榎本 ${ }^{1}$ 1975), PPD 皮内反応, DNCB 反 応とも T 細胞数と平行する（榎本 ${ }^{1} ＼mathrm{~ 1975, ~ 松 ~}$ 井2) 1976). 一般に PPD の方が陽性率が低く (70 80\%)（元谷3) 1964, 村中4) 1969), BCG 接種時期や注射部位の影響を受けやすい。一方， $\mathrm{DNCB}$ 反応は，陽性率は高い（91９7\%) (Young ${ }^{5)}$ 1972, Catalona ${ }^{6}$ 1972) が，反応をみる 
までに感作後 2 週間の期間を必要とし，また， 過敏性皮膚炎を引き起こすという欠点がある。 $\mathrm{PPD}, \mathrm{DNCB}$ とも陽性率にばらつきがあるが， 非特異的免疫能を知るらえで簡便な検査として 有用である。

\section{II. in vitro}

腫瘍免疫の主役であるリンパ球の数, 形態, 機能などを in vitro で分析する種々の方法が開 発され, これによって担癌生体の免疫能を知る ことが可能となった。T細胞ならびにその亜系 細胞の同定と機能について以下に述べる.

1. 口ゼット形成法 (RFC)

ヒト T細胞にはヒツジ赤血球に対するレセプ ターが存在することから， T細胞にヒッジ赤血 球を加えると，ある一定条件下で， $\mathrm{T}$ 細胞の周 囲にヒッジ赤血球が結合しロゼットを形成する 反応を利用したものである.

\section{1) $\mathrm{E}-\mathrm{RFC}$}

ヒツジ赤血球を結合するリンパ球で，正常七 ト末梢血リンパ球の 75 ～85\%が E-RFC を形成 する. 担癌生体では, 全般的に低下 $(37.3 \sim 67.4$ \%）（田端7）1977）の傾向を示寸． T細胞数の 把握には簡便で有用な測定法である。また，リ ンパ球を $37^{\circ} \mathrm{C} て ゙ 60$ 分の前培養後, 赤血球浮遊 液を加え混和，室温で遠心後すぐロゼットの測 定を行ならものが early E-RFC と呼ばれる方 法であり, $\mathrm{T}$ 細胞の一部 $(\mathrm{T} \gamma$ 細胞は含まない8) がロゼットを形成する．末梢血りンパ球の10 $30 \%$ が陽性を示す（新保9） 1988）。担癌患者で は，口ゼット形成率の低下を示し，病態をよく 反映する（新保9) 1988, Wahlin ${ }^{10)} 1983$, 田端11) 1986).

\section{2) EA-RFC}

$\operatorname{IgG}$ 抗体の $\mathrm{Fc}$ 部に対するレセプターを検出 する方法が EA口ゼットであるＩIgGを結合さ せた赤血球を用いてロゼット形成をみる，IgG 抗体を用いた場合にロゼットを形成するのは， $\mathrm{T} \gamma$ 細胞といい，その他， IgM, IgA， IgE およ び $\mathrm{IgD}$ 抗体の $\mathrm{Fc}$ 部に対するレセプターを持つ ものがありそれぞれ $\mathrm{T} \mu, \mathrm{T} \alpha, \mathrm{T} \varepsilon, \mathrm{T} \delta$ と呼ばれ
る (Kiyono ${ }^{12)}$ 1985, Fridman' ${ }^{13)}$ 1981, Morreta ${ }^{14)}$ 1977). $\mathrm{T} \gamma$ 細胞は末梢血 $\mathrm{T}$ 細胞中の $5 〜 20 \%$ を しめ, サプレッサーやキラー細胞としての活性 を持つ. また， $\mathrm{T}$ 細胞中の $60 \sim 70 \%$ は $\mathrm{T} \mu$ 細胞 でヘルパーT細胞としての活性を示す. $\mathrm{T} \gamma$ 細 胞は癌疾患で増加し, 腫瘍の摘出とともに低下 する（新保 ${ }^{15)}$ 1978）。

3) EAC-RFC

活性化された補体系成分に対するレセプタ一 （C3レセプター；CR1，CR2，CR3）が，赤血 球, 好中球, 単球, マクロファージ, B 細胞, 一部の T細胞, 腎系球体上皮細胞に存在する. 末梢血リンハ球中の割合は CR1 : CR2 : CR $3=6$ : $1: 3$ になるといわれ10), K 細胞の40〜 50\%が CR3 陽性で，残りが CR1 と CR2 陽性細胞であ る (Wahlin ${ }^{10)}$ 1983). EAC-RFC の上昇が担癌患 者でみられる (榎本 ${ }^{1)}$ 1976, 田端7) 1977, 田 端11) 1986).

2. リンパ球サブセット

各種のモノクローナル抗体を利用し, 酵素抗 体法や螢光抗体法により, リンパ球の膜抗原を 同定できるよらになった。また，flow cytometry の出現により, リンパ球サブセット の定量化, および two color analysis によって より詳細なサブセットの解析が可能となった。

1) $\mathrm{T}$ 細胞 $\mathrm{B}$ 細胞比

担癌患者では，正常人に比べT細胞が少なく， B 細胞が多い傾向が認められる。また, clinical stage と T, B 細胞の関係については, 転移なし群, 頸部転移群, 遠隔臓器転移群の順 にT細胞は減少する。治療による T, B 細胞の 変動については, 抗癌剤拉よび放射線治療直後 にはT細胞の減少が認められたが，腫瘍の消失 すなわち担癌生体が，なんらかの治療によって 悪性腫瘍から解放された状態では，T細胞は治 療前の值に回復する傾向がみられた. 予後につ いては, retrospective な調査では, 生存例の T細胞が死亡例の T細胞よりも初診時すでに高 く, B 細胞では逆の関係が認められた（榎本 ${ }^{1)}$ 1976). 
2）末梢血 Tリンパ球サブセット

CD4 陽性細胞 (suppressor/cytotoxic T cell) と CD8 陽性細胞 (helper/inducer T cell) の比 $\mathrm{CD} 4 / \mathrm{CD} 8$ 比は，一般に病態と相関する（武 田 ${ }^{16)}$ 1985）といわれているが，CD8 陽性細胞 には, CD8+CD15+ の suppressor $\mathrm{T}$ cell と CD8+CD15-の cytotoxic T cell が含まれてい るためより厳密なサブタイプの比の検討が待た れる。

panNK 細胞の測定には, CD16, Leu19, Leu7 が用いられる。 NK 細胞は主に $\mathrm{CD} 3+\mathrm{CD} 16$ -Leu19+ 細胞と CD3-CD16+Leu19+ 細胞 にわかれ (Lanier ${ }^{17)}$ 1986), 末梢血リンパ球中の それぞれ $5 \% ， 10 \%$ を占め，高い NK 活性を示 す. 頭䅡部悪性腫瘍患者で $\mathrm{NK}$ 細胞数の増加 を示した報告（武田 ${ }^{16)}$ 1985）もあるが，一致 をみていない(Wolf ${ }^{18)}$ 1987).

活性化 T細胞の検索には, HLA-DR 抗原, トランスフェリンレセプター, IL-2 レセプター (CD25) が用いられる.

3）腫瘍内浸潤リンパ球サブセット

腫瘍内浸潤リンパ球 (TIL) の phenotype は, 報告によって異なるが $\left(\right.$ Topalian ${ }^{19)} 1987$, Ito $^{20)}$ 1986, Kurnic ${ }^{21)}$ 1986, Zeromski ${ }^{22)}$ 1988), CD8 陽性細胞が 〜 70\%，CD4 陽性細胞が20～50\%， Leu7 陽性細胞が〜20\%，B細胞が〜30\%を示 すが，IL-2 レセプター陽性細胞は10\%以下で ある(Topalian ${ }^{19)}$ 1987，原㴊23) 1984).

3. 幼若化反応

mitogen(分裂促進因子) を添加し培養する ことによってリンパ球の幼若化反応をみる. mitogen には， $\mathrm{T}$ 細胞の久を特異的に芽球化さ せる T細胞 mitogen とB 細胞にのみ特異的な B 細胞 mitogen がある. PWM は T, B 両細胞 を芽球化させる.

ConA や PWM に上る刺激で CD8 陽性細胞 の増加, CD4/8 比の低下がみられるのに対し, PHA に上る刺激では CD4 陽性細胞の増加, $\mathrm{CD} 4 / 8$ 比の上昇が起こる (Williams ${ }^{24)}$ 1982). ConA/PHA 比がリンパ球反応の評価に有用と
され（沖25） 1984, Stout ${ }^{26)}$ 1975），健常人では PHA 反応の方が ConA 反応より高い值をとる ため, ConA/PHA 比は 1 以下となるが, 癌患 者では 1 以上となることが多い(新保27) 1988)。

\section{4. 細胞障害性}

細胞障害性細胞には, Tc 細胞 (cytotoxic T cell), NK (natural killer) 細胞, K細胞, LAK (lymphokine activated killer) 細胞, マクロフ ァージ，好中球などがある。そのなかで，NK 細胞は感作を必要とせず，生体における第一次 的細胞障害性を有する細胞で，癌に対する防御 機構において重要な役割を担らものと考えられ る. 以下， $\mathrm{NK}$ 活性について述べる。

NK (natural killer) 細胞は, 非担癌生体のリ ンパ球が，ある種の腫瘍細胞に対し細胞障害性 をもつことから (Kiessling ${ }^{28)}$ 1975, Herberman ${ }^{29)}$ 1975, Sendo ${ }^{30)}$ 1975, Zarling ${ }^{31)}$ 1975), 発見者の 一人である Kiessling28)（1975）によって命名さ れた． in vivo における抗腫瘍性に関しても， ヌードマウス（胸腺欠損）の癌発生率が正常、 ウスと差異のないこと (Herberman ${ }^{32)}$ 1978， Hersey ${ }^{33)}$ 1979) などが報告され，NK 細胞は， 癌に対する生体の第一次防御機構において重要 な役割を担うものと考兄られる。

ヒト NK 細胞は, non $\mathrm{T}$, non $\mathrm{B}$, non phagocytic, non adherent cell で，かつ IgGK 対する Fc-recepter (Fc-R)をもつリンパ球様細 胞であるとされている(West ${ }^{34)} 1977$, Herberman ${ }^{35}$ 1975)。さらに， Т細胞のマーカーであるヒッ ジ赤血球に対して低親和性レセプターをもち (West ${ }^{34)}$ 1977, West ${ }^{36)}$ 1978), 補体レセプター に関しては陰性とする報告が多い(Herberman ${ }^{32)}$ 1978)。また, ADCC (antibody-dependant cellullar cytotoxicity) の effector 細胞であるK 細胞とは， IgG-FcR 陽性であること, 競合試験で相互に 活性を防止し得ること(Koide ${ }^{37)}$ 1978) などによ り，注ぼ同一か，少なくとも重複する細胞集団 であると考えられている。

未治療の頭䅡部悪性腫瘍47例, 悪性リンパ腫 7 例, 悪性黑色腫 3 例, 悪性間葉腫, 乳癌頸部 
転移各 1 例, 計59例を対象とし，対照群として 良性腫瘍 8 例，健常人18例を選んで測定した NK 活性について当教室での成績を述べる. effector 細胞は末梢血から Ficoll-Hypaque 比重 遠沈法にてリンパ球を回収し，プラスチックシ ヤーレで培湌液とともに一時間 incubation 後, non adherent cell を用いた。 むた，標的腫瘍細 胞は, 石田ら (1976 $\left.{ }^{38)}, 1968^{39}\right)$ が樹立したヒト 上靧癌由来扁平上皮様腫瘍細胞 (OKK cell line) を用い， ${ }^{51} \mathrm{Cr}$ release assayによって活性を測定 した。

\section{1）健常人との比較}

健常人，良性抒よび悪性腫瘍患者リンパ球の $\mathrm{NK}$ 活性を $\mathrm{E} / \mathrm{T}$ 比 $50: 1$, 反応時間 20 時間で比 較してみると（図 1)， $\mathrm{NK}$ 活性の平均值扣よ び S.D. は健常人 $32.3 \pm 12.9 \%$ ，良性腫瘍 35.6 $\pm 19.6 \%$ ，悪性腫瘍 $25.3 \pm 14.3 \%$ となり，健常 人と良性腫瘍患者群との間には有意差はなく, 悪性腫瘍患者では，有意に $(\mathrm{p}<0.05) \mathrm{NK}$ 活性 が低下していた（兼 ${ }^{40)} 1984 ）$.

2) 病期の進行と NK 活性

悪性患者の NK 活性を clinical stage (UICC) 別に調べてみると（図 2), stage I の NK 活性 は33.9 7.1 と高く健常人レベルであった。

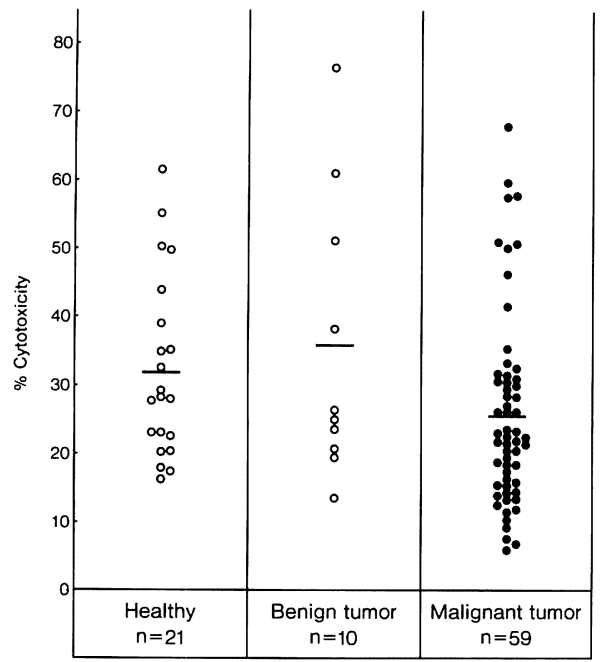

図1健常人拉よび腫瘍患者（良性, 悪性)リンパ 球の NK 活性（E/T ratio, $50: 1)$ stage II で22.4土11.4\%と低下傾向を示し，以 後, stage III $23.0 \pm 14.2 \%$, stage IV $21.7 \pm$ $9.6 \%$, 病期の進行にともない徐々に低下寸 ることが示唆された.

3） NK 活性におよぼす自己血清の影響

健常人リンパ球の NK 活性に対する自己血 清の影響について検討してみると, FCS (fetal calf serum) で NK 活性は28.1 10.8 であった のに対し，自己血清では， $55.7 \pm 8.2 \%$ と二倍 の值を示した。 また，ABS (AB serum) でも

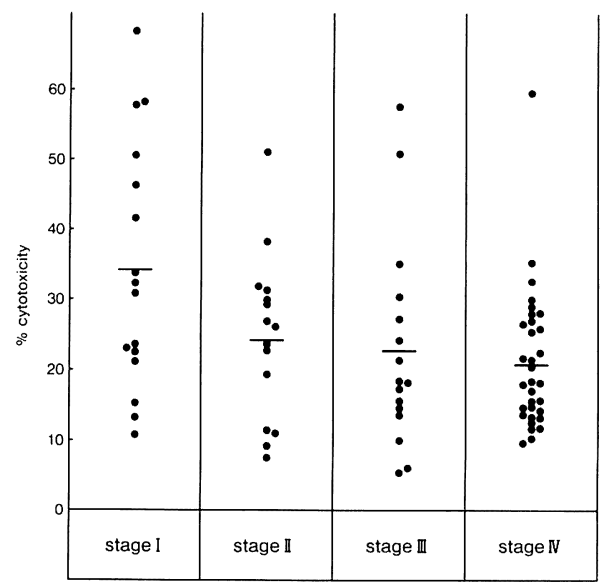

図 2 悪性腫瘍患者リンパ球の NK 活性（E/T ratio, $50: 1)$

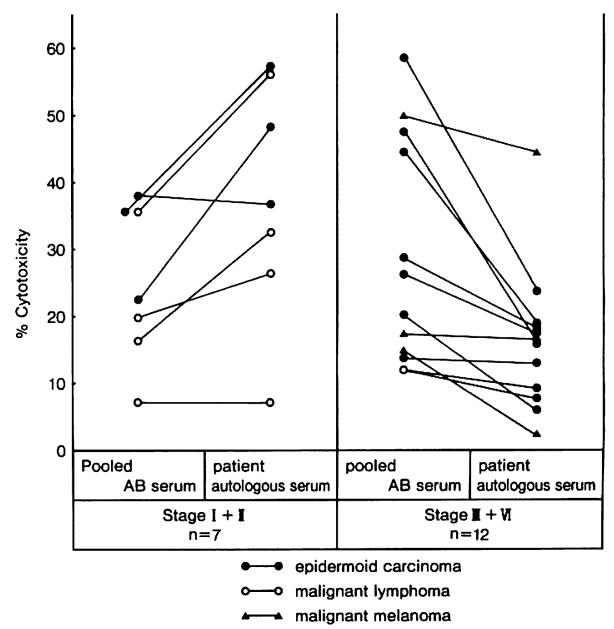

図 3 悪性腫瘍患者リンパ球 NK 活性におよぼす自 己血清の影響 
$49.7 \pm 15.8 \%$ と高值を示したが，自己血清の方 が増強効果が強い傾向がみられた。

これに対して, 担癌患者の自己血清の場合 (図 3 ）は, 初期癌, すなわち stage I+II の患者 血清の多く（5/7）は健常人と同様のパターンを 示したが，汇とんど影響のないもの，やや低下 させるものもみられ，これらはいずれも stage II の患者であった。また, stage III+IV の進 行癌に扣いて，多くの血清は NK 活性を抑制 する傾向を示し，この抑制効果は標的細胞と同 種の癌患者のみならず，覀性黒色腫，悪性リン 八腫患者血清に执いて子観察され，非特異的因 子の関与が考学られた。

NK 活性を抑制する因子については, Koren ら 41)（1981）は PGE (prostaglandin E)をあげて いる、そのほか， NK 抑制性マクロファージ の存在 (Koren ${ }^{41)}$ 1981, Puccetti42) 1979), Fab fragment 抗ヒト IgG (Troye ${ }^{43)}$ 1976), 血清中の 免疫抑制 immune complex (Thefilopoulos ${ }^{44}$ 1976) などが報告されている.

\section{5. 免疫抑制因子}

担癌生体の免疫応答の調節は腫瘍抗原に特異 的な液性, 細胞性免疫以外に, 体液中の種々の 非特異的免疫物質によってもなされることが， 知られている（漆崎 ${ }^{45)} 1982$ ，兼 ${ }^{46)}$ 1984）。また, これらの反応は癌の進行度と相関し腫瘍の増大 は担癌生体の免疫能の低下を反映するが，血清 中にみられる種々の非特異的免疫抑制因子の増 加も見過ごすことはできない。

これらの因子のなかで, IAP (immunosuppressive acidic protein) は担癌生体血清や腹水 中から単離された，等電点 3.0 , 分子量 50,000 の酸性蛋白であり（松田 ${ }^{47)}$ 1977, 松田 ${ }^{48}$ 1978), PHA によるリンパ球幼若化，リンパ球混合反 応等の免疫反応を著しく阻害するものと報告さ れている（石田49) 1980，松田50) 1976）。その後, 各種癌患者血清中の IAP 值は正常人に比較し て有意に高く, 癌の進行度, 治療効果の判定の モニターとして有用であるとの報告が数多い （大嶋51）1981，佐藤52）1981，北村53) 1981）。
頭頸部悪性腫瘍患者の血清 IAP について, 兼ら ${ }^{46)}(1984 ）$ は, 扁平上皮癌では平均 IAP 值 $697.4 \mu \mathrm{g} / \mathrm{ml}$, 陽性率 $69.6 \%$, 悪性リンパ腫で はさらに高く, $829.0 \mu \mathrm{g} / \mathrm{ml}$, 陽性率 $83.3 \%$ を 示し，これは特に IAP が高值とされる肺癌 (宮本 ${ }^{54}$ 1980), 大腸癌 (石田 ${ }^{49}$ 1976), 膵癌 (松 野55）1980）に匹敵する值であった。ささら癌 の進行度に関しては, stage I 群では正常值の 平均を示したが, stage II 群以降で早くも高值 をとる例が多くなり, 平均 IAP 值は stage II 群 665.0, stage III 群 800.0, stage IV 群 $888.2 \mu \mathrm{g} / \mathrm{ml}$, 陽性率も，それぞれ, 60.0， 71.4， $81.8 \%$ と著しい増加を示し, 頭頸部悪性腫瘍に おいて血清 IAP は癌の進行度とよく相関する としている（図４）。また，NK 活性と血清 IAP との間には有意 $(\mathrm{P}<0.05)$ な負の相関を認 めたと報告している（兼46)1984）（図 5 ）.

林ら ${ }^{56)}$ （1984）は，疾患別に IAP 值を調べ, 咽頭癌, 悪性リンパ腫で高值を示し, 喉頭癌で 比較的低值を示したとしている。

他の免疫学的パラィーターとの関係では, PPD 皮内反応，E-RFC と負の相関を示したが，

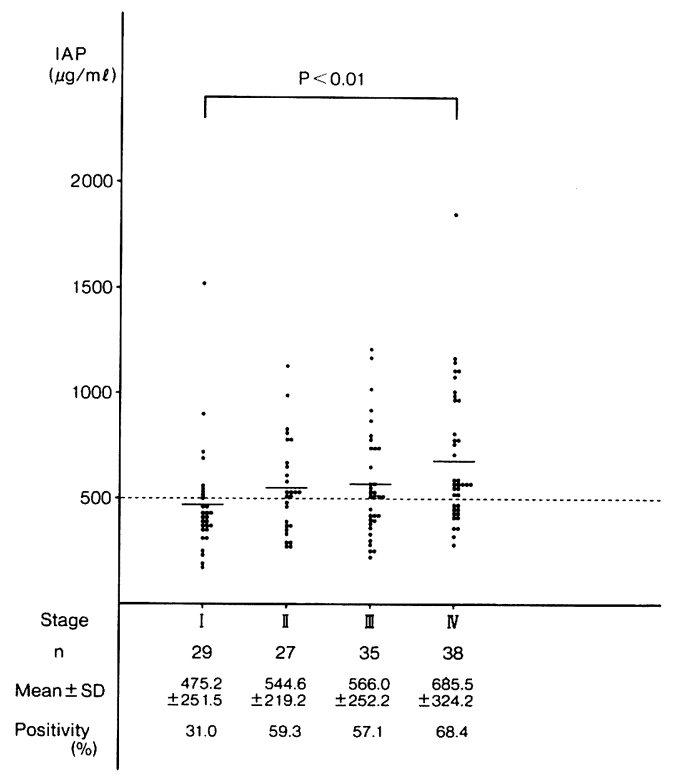

図 4 stage 別治療前血清 IAP 值 
EA-RFC, EAC-RFC, IgG，IgA，IgM 等とは相 関が認められなかったことから，IAP は非特 異的に細胞性免疫能を抑制することを示唆した (林56) 1984).

また, IAP と同様の免疫抑制活性を示す物 質に IS (immunosuppressive substance) がある. IS は藤井ら 57)（1980）によって末期大腸癌患者 腹水から分離された分子量 52,000 , 当電点 2.7 3.3 , 糖含量 $13 \%$ の酸性蛋白で, $\mathrm{T}$ 細胞から産 生され，リンパ球幼若化反応の抑制などの作用

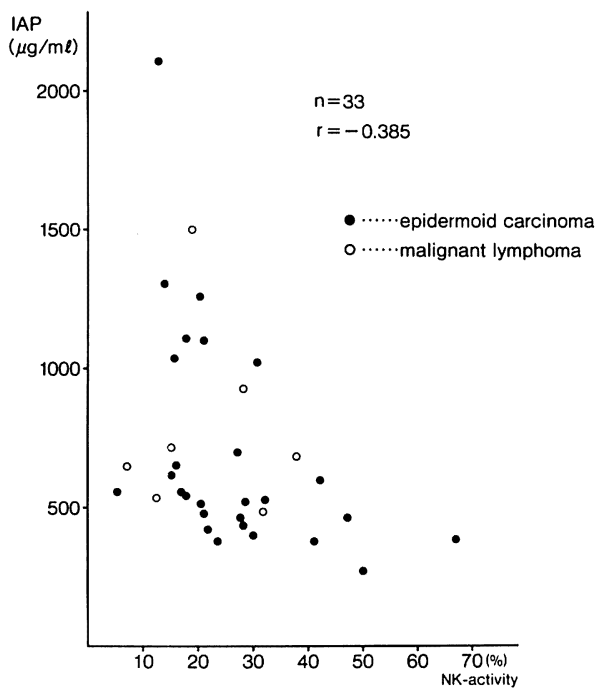

図 5 頭頸部悪性腫瘍患者血清 IAP 值と NK 活性

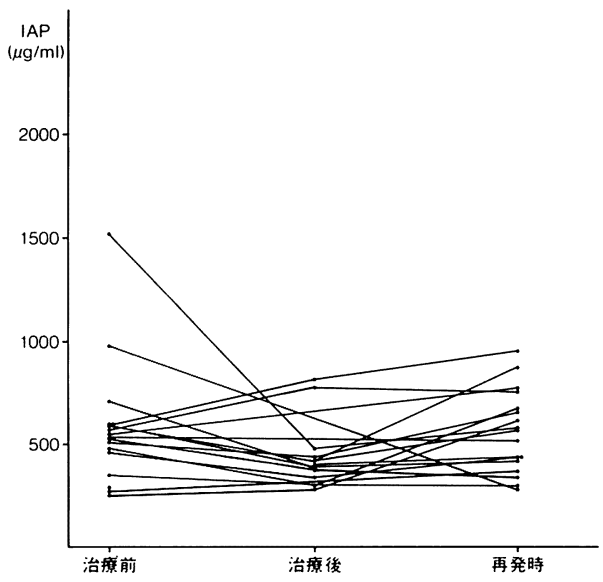

図 6 再発症例の血清 IAP 值
が報告されている（浜田 ${ }^{58)} 1984 ）$.

斉藤ら ${ }^{59)}$ (1989)は, 頭頸部悪性腫瘍患者149例 を対象に IAP, IS を測定し, 上罘癌, 下咽頭 癌, 悪性リンパ腫では高値を示し, 喉頭癌, 甲 状腺癌では比較的低值を示したとしている. 臨 床病期との関係では, IAP と同様に stage の進 行と相関を示し, 再発時には, IAP, IS 值と も上昇を示した（図 6 ）ことから治療後 IAP, IS 值が再上昇する例では再発に注意が必要と している（斉藤59) 1989）.

\section{おわりに}

癌に対する治療は集学的治療の形で行なわれ， そのなかで，免疫療法の果たす役割は大きい。 癌免疫療法は, 人に元来備わっている免疫を賦 活増強することによって扣こなわれるより生理 的な治療法である.

癌に対する生体の反応は, 単一の経路で扣こ なわれているのではなく，種々の反応が複雑に 絡及合っておこなわれている. 従って, 癌に対 する生体の免疫能は総合的に判定されるべきで あるが，そのなかで何が最も重要な役割を担っ ているかを突き止めることは治療を行ならにあ たって大切なことである.

さまざまな BRM (biological response modifier）の解明が進み，また，各種モノクローナル 抗体の精製による effector 細胞の解析, 腫瘍特 異抗原の追求などにより, 腫瘍と effector 細胞 の相互作用が明らかになるとともに，癌免疫療 法はより active な方向へと進みつつある。

さらに詳細な研究がなされ, 臨床に応用され る日が待たれる.

\section{参考文献}

1）榎本雅夫, 松井和夫, 田端敏秀, 他：悪性腫瘍 の免疫学的アプローチ (第 1 報)担癌患者の $\mathrm{T}$, B cell の動態と PPD 皮内反応を中心として. 耳鼻臨床 $68: 1147 \sim 1156,1975$.

2）松井和夫, 榎本雅夫, 田端敏秀: 悪性腫瘍の免 疫学的アプローチ（第 3 報）担癌患者の $\mathrm{PPD}$ 皮内反応と DNCB 皮内反応について。耳鼻臨 床 $69: 249 \sim 253,1976$. 
3）元谷喜久夫，他：担癌生体の免疫反応に関する 研究. 癌の臨床 $10: 458 \sim 468,1964$.

4）村中俊明：昭和 43 年結核実態調查. 結核 44 : 325 332, 1969.

5) Young RC, Corder MP, Haynes HA, et al : Delayed hypersensitivity in Hodgikin's disease. Amer J Med $52:$ 63 72, 1972.

6) Catalona WJ, Taylor PT and Cretien PB : Quantative dinitrochlorobenzene contact sensitization in a normal population. Clin Exp Immunol $12: 325 \sim 333,1972$.

7）田端敏秀, 兼 典子, 木村通郎, 他 : 悪性腫瘍 の免疫学的アプローチ（第 7 報）培養細胞を Targetとした担癌患者リンパ球の Microcytotoxicity Assay について. 耳鼻臨床 $70: 283 \sim 290,1977$.

8) West WH, Paune SM, Weese JL, et al : Human T lymphocyte subpopulations; correlation between E-rosette-forming affinity and expression of the Fc recept-or. J Immunol 119 : 548 554, 1977.

9）新保敏和：免疫パラメーター；癌患者における 臨床的意義とその測定法. II. リンパ球サブセ ット. BIOTHERAPY 2 : 3; 618 634, 1988.

10) Wahlin B, Perlmann H, Perlmann p, et al : C3 receptors on human lymphocyte subsets and recruitment of ADCC effector cells by $\mathrm{C} 3$ fragments. J Immunol 130 : 2831 2836, 1983.

11）田端敏秀: 免疫パラメーターの読み方. 図説臨 床耳鼻咽喉科講座 $5: 66 \sim 67,1986$.

12) Kiyono H, Mosteller-Barnum LM, Pitts AM, et al : Isotype-specific immunoregulation. IgAbinding factors produced by $\mathrm{Fc} \alpha$ receptorpositive $\mathrm{T}$ cell hybridomas regulate $\operatorname{Ig} \mathrm{A}$ responses. J Exp Med 161 : 731 747, 1985.

13) Fridman WH, Rabourdin-Combe $C$, Neau portSautes $\mathrm{C}$, et al : Characterization and function $\mathrm{T}$ cell $\mathrm{Fc}_{\boldsymbol{}}$ receptor. Immunol Rev $56: 51 \sim 88$, 1981.

14) Moretta L, Webb SR, Grossi CE, et al : Functional analysis of two human T-cell subpopulations; help and suppression of $\mathrm{B}$ cell responses by $\mathrm{T}$ cells bearing receptors for $\operatorname{IgM}$ or IgG. J Exp Med $146:$ 184 200, 1977.
15）新保敏和, 麦谷 夫, 菅原真智子, 他 : 癌患者 でみられるリンパ球とマクロファージの異常. 癌と化学療法 $5: 261 \sim 272,1978$.

16）武田哲男, 古内一郎, 馬場廣太郎 : 頭頸部悪性 腫瘍における T細胞亜群と NK 細胞について 一FACS による解析一. 日耳鼻 $88: 1652 \sim 1658$, 1985.

17) Lanier LL, Le AM, Civin CI, et al : The relationship of CD16 (Leu-11) and Leu-19 (NKH-1) antigen expression on human peripheral blood NK cells and cytotoxic T lymmphocytes. J Immunol $136: 4480 \sim 4486,1986$.

18) Wolf GT, Schmaltz S, Hudson J, et al : Alterations in T-lymphocyte subpopulations in patients with head and neck cancer : correlations with prognosis. Arch otolaryngol head and neck surg 113:11; 1200 1206, 1987.

19) Topalian SL, Muul LM, Solomon D, et al : Expansion of human tumor infiltrating lymphocytes for use in immunotherapy trials. J Immunol Methods $102: 127 \sim 141,1987$.

20) Ito K, Arabella BT and Balch CM : Interleukin 2 activation of cytotoxic $\mathrm{T}$ lymphocytes infiltrating into human metastatic melanomas. Cancer Res $46: 3011 \sim 3017,1986$.

21) Kurnic JT, Kradin RL, Blumberg R, et al : Functional characterization of $\mathrm{T}$ lymphocytes propagated from human lung carcinomas. Clin Immunol Immunopath 38 : 367 380, 1986.

22) 'Zeromski J, Pietrzak J, Szmeja Z, et al : Evaluation of phenotipe of mononuclear host cells isolated from primary tumour and peripheral blood of patients with laryngeal carcinoma. J Immunol Methods $105: 1,2 ; 149 \sim 154,1988$.

23）原澕保明，山中 昇, 形浦昭克：頭頝部癌に拈 ける局所免疫応答一癌組織浸潤細胞の免疫組織 学的解析一. 耳喉 $56: 7 ; 487 \sim 490,1984$.

24) Williams JM, Shapiro HM, Milford EL, et al : Multiparameter flow cytometric analysis of lymphocyte subpopulation activation in lectinstimulated cultures. J Immunol $128: 2676$ 2681, 1982.

25）沖一，一色立雄，笠野 満，他：悪性腫瘍 患者のリンパ球 subpopulation, $\mathrm{T}$ cell subsette 
の各占有率とレクチン反応性について. 臨床病 理 $32: 159 \sim 164,1984$.

26) Stout RD and Herzenberg LA : The Fc receptor on thymus-derived lymphocyte. II Mitogen responsiveness of $\mathrm{T}$ lymphocytes bearing the Fc receptor. J Exp Med 142 : 1041 1051, 1975.

27）新保敏和：免疫パラメーター；癌患者にお打る 臨床的意義とその測定法一III リンパ球の増 殖一. BIOTHERAPY $2: 4 ; 798 \sim 818,1988$.

28) Kiessling $\mathrm{R}$, Klein $\mathrm{E}$ and Wigzell $\mathrm{H}$ : Natural Killer cells in the mouse. I Cytotoxic cells with specificity for mouse moloney leukemia cells. Specificity and disttribution according to genotype. Eur J Immunol 5 : 112 117, 1975.

29) Herberman RB, Nuun $\mathrm{ME}$ and Levin $\mathrm{DH}$ : Natural cytotoxic reactivity of mouse lymphoid cells against syngeneic and allogeneic tumours; I distribution of reactivity and specificity. Int $\mathrm{J}$ Cancer $16: 216 \sim 229,1975$.

30) Sendo F, Aoki T, Boyse EA, et al : Natural occurrence of lymphocytes showing cytotoxic activity to $\mathrm{BALB} / \mathrm{c}$ radiation induced leukemia RL ơ 1 cells. J Natl Cancer Inst $55: 603 \sim 609$, 1975.

31) Zarling JM, Novinski RC and Bach FH : Lysis of leukemia cells by spleen cells of normal mice. Proc Natl Acad Sci USA 72 : 2780 2784, 1975.

32) Herberman RB and Holden HT : Natural cellmediated immunity. Adv Cancer Res 27 : 305 $\sim 317,1978$.

33) Hersey P, Edward A, Honeyman M, et al : Low natural killer cell activity in familial melanoma patients and their relatives. Brit $\mathrm{J}$ Cancer $40:$ 113 122, 1979.

34) West HW, Cannon GB, Kay HD, et al : Natural cytotoxic reactivity of human lymphocytes against a myeloid cell line; characterization of effectorcells. J Immunol 118 : 355 361, 1977.

35) Herberman RB and Holden HT : Natural killer cells as antitumor effector cells. J Natl Cancer Inst $62: 441 \sim 445,1975$.

36) West WH, Boozer RB and Herberman RB : Low affinity E-rosette formation by human $\mathrm{K}$ cell. J Immunol 120 : 90 95, 1978.

37) Koide $Y$, Kwok R and Takasugi M : Studies of effector cell antibody and target cell interaction in cell mediated cytotoxicity. Int J Cancer 22 : 546 551, 1978 .

38）石田 稔, 中島幸雄, 井上博雄 : 上顎癌原発の 人癌細胞の培湌. 日耳鼻 $79: 686 \sim 694,1976$.

39）石田 稔. 里見真美子, 新宮浩寿 : 七上上顎癌 に関する研究(第一報). 成人病 $17: 686 \sim 694$, 1968.

40）兼 典子：頭頸部悪性腫瘍患者リンパ球の NK 活性について.和歌山医学 $34: 1 ; 27 \sim 35,1983$.

41) Koren HS, Anderson SJ, Fisher DG, et al : Regulation of human natural killing; I The role of monocytes, interferon and prostaglandins. J Immunol $127:$ 2007 2013, 1981.

42) Puccetti P, Santoni A, Riccardi C, et al : Activation of mouse macrophages by pyran copolymer and role in augmentation of natural killer activity. Int J Cancer 24 : 819 825, 1979.

43) Troye M, Perlman P, Pape GR, et al : The use of Fab fragments of anti-humanimmunoglobluin as analytic tools for establishing the involvement of immunoglobulin in the spontaneous cytotoxicity to cultured tumor cells by lymphocytes from patients with bladder carcinoma and from healthy donors. J Immunol $119: 1061 \sim 1067,1977$.

44) Thefilopoulos AN, Wilson CB and Dixon FJ : The Raji cell radioimmune assay for detecting immune complexes in human sera. J Clin Invest $57: 169 \sim 182,1976$.

45) 漆崎一郎：Biological Response Modifiers (BRM) 体液物質. 癌と化学療法 9 Suppll 1 : 128 139, 1982.

46）兼 典子, 椋代光夫, 获良博, 他: 頭頸部悪 性腫瘍に抢ける血清 IAP (immunosuppressive Acidic Protein) 值の臨床的意義.耳鼻臨床 77 : 457 463, 1984.

47）松田好史, 本木宏昭, 北目文郎, 他: 癌患者血 清中に発見された免疫抑制活性を示す酸性蛋白. 医学のあゆみ $102: 747 〜 749,1977$.

48）松田好史, 田村啓二, 北目文郎, 他 : 癌患者血 清中に存在する免疫抑制酸性蛋白 (IAP) の性状 
と免疫抑制活性. 医学のあゆみ $105: 154 \sim 157$, 1978.

49）石田名香雄, 田村啓二, 柴田芳実 : 免疫抑制酸 性蛋白の性状と癌患者に打ける検出意義. 医学 のあゆみ $115: 423 \sim 433,1980$.

50）松田好史，佐藤寿雄：担癌宿主の免疫抑制酸性 蛋白 (IAP) と外科手術. 日外会誌 $80 ： 1395 \sim$ 1398, 1976.

51）大嶋一徳, 清水敬生, 甲田徹三, 他 : 各種悪性 腫瘍および肝硬变患者における血清免疫抑制酸 性蛋白 (IAP) について。癌と化学療法 II : 1756 $\sim 1764,1981$.

52）佐藤 真, 山崎忠光, 菊嶋慶昭, 他: 胃癌患者 における術前術後の免疫抑制蛋白 (IAP) と各種 免疫指標の関連について. 癌と化学療法 8： 1053 1059, 1981.

53）北村正次, 富永 健, 林 和雄, 他: 乳癌患者 における血清 IAP 值および血中 CEA 值測定の 臨床評価. 癌と化学療法 II：1765～1769, 1981.

54）宮本 宏, 井上勝一, 村尾 誠: 肺癌患者に拉 ける血清中の免疫抑制酸性蛋白 (IAP) 測定の意 義について.診断と新薬 $17: 2854 \sim 2859,1980$.
55）松野政紀, 小針雅男, 松田好史, 他: 膵癌に拉 ける免疫抑制性蛋白 (IAP) の測定の意義. 日消 病会誌 $77: 430,1980$.

56）林 泰弘, 兼 典子, 竝 良博: 頭頸部悪性腫 瘍に扰ける血清 (IAP) 值の検討一血清 IAP (immunosuppressive Acidic Protein) と尒後ならび に免疫学的パラメーターとの関係について一. 耳鬾臨床 $77: 1177 \sim 1185,1984$.

57）藤井雅彦, 高橋則男, 他 : 癌患者腹水中の免疫 抑制物質 (IS) の分離之性状について。第39回 日本癌学会総会記事：119, 1980.

58）浜田史洋, 滜本定義, 他：免疫抑制物質（IS 物質）の細胞性免疫抑制機序. 第43回日本癌学 会総会記事：109,1984.

59）斉藤匡人, 獄 良博, 垣内 弘, 他: 頭頸部癌 における免疫抑制因子 (IAP, IS) 臨床的意義.

日耳鼻 $92 ： 588 \sim 596,1989$.

$$
\left(\begin{array}{l}
\text { 別刷請求先 : 與田順一 } \\
\mathbf{T} 640 \text { 和歌山市七番丁 } 27 \\
\text { 和歌山県立医科大学耳鼻咽喉科学教室 }
\end{array}\right)
$$

